\title{
Examining High School Students' Ill-Structured Problem Solving Skills on Chemistry Problems Related to COVID-19
}

\author{
Cety Anggun Widyorini ${ }^{1,}$ Sri Rahayu ${ }^{2, *}$ \\ ${ }^{1}$ Master of Chemistry Education, Faculty of Mathematics and Natural Sciences, Universitas Negeri Malang, \\ Indonesia \\ ${ }^{2}$ Department of Chemistry, Faculty of Mathematics and Natural Sciences, Universitas Negeri Malang, Indonesia \\ ${ }^{*}$ Corresponding author. Email: sri.rahayu.fmipa@um.ac.id
}

\begin{abstract}
This study is preliminary research that aims to examine high school students' ill-structured problems solving skills on chemistry problems related to COVID-19. This study used a mixed-methods research design. The participants of this study were 70 senior high school students (16-17 years old) that were selected by convenience sampling from several regions in East Java Province (Malang, Banyuwangi, and Tulungagung). The research instrument consisted of 2 ill-structured chemistry problem texts related to COVID-19 issues. Each problem consisted of 9 question prompts. The instrument has high reliability (Cronbach's Alpha coefficient $=0.774$ ). The result of this study showed that the highest percentage of students' ill-structured problem solving skill is the stage of problem representation $(37.74 \%)$ and the lower percentage is the stage of making justifications $(24.40 \%)$. The result of this study also showed that only $8.57 \%$ (6 students) on problem 1 and $10.00 \%$ ( 7 students) on problem 2 solved the problem based on the chemistry concept (chemical bonding, hydrocarbon compound, and polymer) while the others solved the problems based on social, economic, environmental, and health aspect. That result indicated that student was lack of ability to apply chemistry concept to solve their everyday life problems. Therefore, teachers need to apply more ill-structured problem solving in the chemistry learning.
\end{abstract}

Keywords: Ill-structured problem solving, Chemistry problem, COVID-19

\section{INTRODUCTION}

Many problems in everyday life are ill-structured problem and create dilemmas. Ill-structured problems are complex problems, the elements of the problem are not explicitly defined, require other relevant information, and can add up due to a variety of solutions from various points of view [1]. This problem becomes a challenge for students as individuals with scientific literacy. Therefore, problem solving skills are one of the necessary skills needed by students in everyday life [2]. The 2018 PISA shows that Indonesia is ranked $74^{\text {th }}$ out of 79 countries in the category of scientific literacy [3]. This result is an indicator which states that Indonesian students have not been able to implement scientific concepts to solve problems in everyday life.

Previous research stated that science learning, including chemistry, tends to be oriented towards well-structured problems [4]. On well-structured problems, the elements of the problem are stated explicitly [5]. Students apply a concept, algorithmic calculation, or a particular scientific procedure to obtain a correct solution [1]. In chemistry studies, one example of a well-structured problem is determining the $\mathrm{pH}$ value of a weak acid solution with molarity and ionization constant known. Ill-structured problems cannot be developed only by applying a specific concept [6], [7], but also require the integration of several domains of knowledge, for example problem solving of pollution that require integration of chemical, biological, mathematical, social, economic, and psychological concepts [5]. The cognitive and metacognitive components needed by students in the ill-structured problem solving process are also different from well-structured problems [1]. This condition causes students tend to have difficulty in implementing the problem solving skills they acquire 
in school to solve problems in everyday life [4]. Therefore, students who succeed in solving wellstructured problems in school will not necessarily be successful in transferring their knowledge to solve problems in everyday life [8].

The ill-structured problem solving process consists of four stages, which are the stage of problem representation, generating and selecting solutions, making justifications, and monitoring and evaluating solutions [9], [10]. At the stage of problem representation, students identify the core of the problem, generate problem solving goals, and the factors that cause the problem [1], [11], [12]. Students also have to identify whatever their prior knowledge and experience is related to the problem [9]. Thus, students' prior knowledge is one of the factors that can affect their ability to represent problems [13], [14]. At the stage of generating and selecting solutions, students develop solutions based on the results of the representation of the problem [9]. In preparing the solution, students must review the related parties who feel the impact of these problems [1]. Based on the characteristics, ill-structured problems possess a variety of solutions, because the solutions developed on structured problems arise from the student's point of view in representing the problem [1]. At the stage of making justifications, students must construct arguments to support their solution [15]. Students must also provide evidence or data that can support their claim and a warranted statement to strengthen the relevance of the claim to the data [16]. At the stage of monitoring and evaluating solutions, students review the solutions they have synthesized [11]. Students' metacognitive skills are critical at this stage [9]. Students must be able to evaluate their solution by examining and defending it against from various supporting solutions to solve these problems [17]. Students must also be able to reflect themselves to see whether they have identified all the factors that cause problems and whether problem solving goals can be achieved in their applied solutions [9]. At this stage, students must also explore alternative solutions that might be applied to the problems given [1].

The learning process based on ill-structured problem solving is very suitable to be applied in chemistry learning. Understanding chemistry concepts can help students to understand and explain phenomena that occur in the surrounding environment [18]. Many socio-scientific issues (SSI) in everyday life are related to chemistry concepts, for example, climate change, energy, and environmental pollution [19]. SSI are controversial, ill-structured, complex, and not only affects the scientific field, but also on other fields, such as politics, economics, social and ethics [20], [21]. These SSI characteristics are very compatible with the characteristics of the ill-structured problem. Therefore, students' ill-structured problem solving skills in chemistry learning can be identified by integrating SSI as a problem aspect [22]. Based on previous research, integration of SSI increase students' interest in taking an active role in solving social science problems in the surrounding environment [23], [24]. In this study, SSI was used as the aspect of the problem, which is chemistry problems related to COVID-19. COVID-19 is a complex social problem and is very suitable as a basis for problem-based learning [25]. Issues regarding COVID-19 such as the dilemma of using anti-bacterial soap and single-use plastics to prevent the transmission of the COVID-19 are related to chemistry concepts, namely chemical bonding, hydrocarbon compound, and polymer.

One of the factors causing the low implementation of ill-structured problem solving in science learning, including chemistry, is the lack of research results that can show the students' ill-structured problem solving skills [26]. This condition causes teachers tend to have difficulty to design appropriate learning methods [8]. Another contributing factor is the lack of valid instruments that can be used to identify students' illstructured problem solving skills [27]. Research in the field of chemistry education tends to focus on improving students' conceptual understanding, but it is not balanced with its application in everyday life and the development of basic science skills, such as problem solving skills [28]. Based on the various problems described earlier, this study aims to examine students' ill-structured problem solving skills at the stage of problem representation, generating and selection solutions, making justifications, and monitoring and evaluating solutions in solving chemistry problems related to COVID-19 issues.

\section{RESEARCH METHODS}

\subsection{Research Design}

This study is a preliminary study using the mixedmethods with embedded design, the method of collecting quantitative and qualitative data which is carried out simultaneously [29]. Quantitative data was collected through a 60-minutes test of students' illstructured problem solving skills. Analysis of student answer data was carried out using a scoring rubric adapted from [17]. Qualitative data was collected through semi-structured interviews with 5 high school students who were selected based on category of the students' developed solutions (chemistry concept, social, economic, environmental, and health aspect). 
The purpose of the semi-structured interview was to obtain more detailed information about the students' ill-structured problem solving process.

\subsection{Participants}

The research samples were 70 high school students (16-17 years old) in several regions in East Java, which are Malang (30.00\%), Banyuwangi $(28.57 \%)$, and Tulungagung $(41.43 \%)$. The participants in each region selection was carried out by convenience sampling, the method of selecting samples based on the availability and possible affordability of the population area [30].

\subsection{Instrument}

The instrument used in this study was an essay with two texts on chemistry problems related to the socio-scientific issues of COVID-19. Each problem consists of 9 question prompts. The question prompts was developed according to the four stages of the illstructured problem solving process, according to [17]. Problem text 1 (P1) entitled "Anti-bacterial Soap or Regular Soap: Which is Better during the COVID-19 Pandemic?" discusses the dilemma of using antibacterial soap which is thought to cause resistant bacteria, skin allergies, and hormonal system disorders, however, the presence of the anti-bacterial soap industry benefits the economic and labour sectors in Indonesia. These problems involve the concepts of chemical bonding and molecular polarity. The problem text 2 (P2) entitled "Single-Use Plastics Is Popular Again During the COVID-19 Pandemic" discusses the dilemma of using single-use plastics as an effort to prevent the transmission of COVID-19, but these efforts have led to an increase in plastic waste in Indonesia. The processing of plastic waste through the improper combustion process in an incinerator can cause the production of $\mathrm{CO}$ gas and dangerous chemical compounds, such as dioxins. These problems involve the concepts of polymers and the combustion reaction of hydrocarbon compound. The reliability of the test instrument used in this study had a high level of reliability criteria (Cronbach's Alpha Coefficient = 0.774 ) which was tested on 70 high school students.

\subsection{Data Analysis}

Quantitative data in this study is the percentage of students' ill-structured problem solving skills which are analysed based on student performance at each stage of the problem solving process, namely problem representation, generating and selecting solution, making justifications, and monitoring and evaluating solutions based on the Equation (1). In the second stage, the solutions developed by students for each problem were also categorized into several aspect, namely chemistry, social, economic, environmental, and health aspect. The percentage of each category of solution is determined based on the Equation (2).

$\%=\frac{\text { total score on indicator-n of } \mathrm{x}^{\text {th }} \text { stage }}{\text { maximal score } \cdot \text { number of participants }}$

$\%=\frac{\text { number of students who answered based on } \mathrm{n} \text { aspect }}{\text { number of participants }}$

The results of the quantitative data analysis were triangulated with qualitative data based on the transcripts of semi-structured interviews with several students, in order to obtain a more detailed explanation of the students' answers and processes in solving the ill-structured problems.

\subsection{Inter Rater Reliability Test}

Reliability between the two researchers was analysed using the Cohen-Kappa coefficient value. The results of the analysis show that there is a significant correlation between the two researchers' assessments at the four stages of ill-structured problem solving with 0.843 of kappa coefficient value. These results indicate that the application of the scoring and analysis system based on the scoring rubric between the two researchers is consistent.

\section{RESULT AND DISCUSSION}

The percentage of students' ill-structured problem solving skills were obtained at each stage of illstructured problem solving is described in Table 1 . Based on the data in Table 1, the highest mean percentage of students' ill-structured problem solving skills occurred in the first stage, problem representation, while the lowest average percentage was in the third stage, making justifications.

\subsection{Students' Ill-Structured Problem Solving Skills at The Stage of Problem Representation}

The data in Table 1 shows that the highest percentage of indicators for students' ill-structured problem solving skills at the stage of problem representation, namely identifying the core of the problem $(48.57 \%)$. The analysis result showed that $84.28 \%$ (59 students) in P1 and $78.57 \%$ (55 students) in $\mathrm{P} 2$ tend to represent the core of the problem in general or not clearly. 
Table 1. Percentage of students' Ill-structured problem solving skills at each stage

\begin{tabular}{|c|c|c|c|}
\hline $\begin{array}{l}\text { The stages of } \\
\text { Ill-structured } \\
\text { problem } \\
\text { solving Process }\end{array}$ & Indicators & $\%$ & $\begin{array}{l}\text { Mean } \\
(\%)\end{array}$ \\
\hline \multirow{4}{*}{$\begin{array}{l}\text { Problem } \\
\text { representation }\end{array}$} & $\begin{array}{l}\text { Define the } \\
\text { problem }\end{array}$ & 48.57 & \multirow{4}{*}{37.74} \\
\hline & Generate goals & 45.71 & \\
\hline & $\begin{array}{l}\text { Identify the } \\
\text { factors causing } \\
\text { the problem }\end{array}$ & 37.86 & \\
\hline & $\begin{array}{l}\text { Identify } \\
\text { relevant } \\
\text { information }\end{array}$ & 18.81 & \\
\hline $\begin{array}{l}\text { Generating and } \\
\text { selecting } \\
\text { solutions }\end{array}$ & $\begin{array}{l}\text { Select or } \\
\text { develop a } \\
\text { solution with } \\
\text { an explicit } \\
\text { explanation }\end{array}$ & 35.71 & 35.71 \\
\hline \multirow{2}{*}{$\begin{array}{l}\text { Making } \\
\text { justifications }\end{array}$} & $\begin{array}{l}\text { Construct an } \\
\text { argument }\end{array}$ & 29.29 & \multirow{2}{*}{24.40} \\
\hline & $\begin{array}{l}\text { Provide the } \\
\text { evidence }\end{array}$ & 19.51 & \\
\hline \multirow{2}{*}{$\begin{array}{l}\text { Monitoring and } \\
\text { evaluating } \\
\text { solutions }\end{array}$} & $\begin{array}{l}\text { Evaluate the } \\
\text { solution }\end{array}$ & 38.57 & \multirow[b]{2}{*}{29.82} \\
\hline & $\begin{array}{l}\text { Assess } \\
\text { alternative } \\
\text { solutions }\end{array}$ & 21.07 & \\
\hline
\end{tabular}

Student performance in representing the core of the problem has an impact on the solutions developed. Therefore, the stage of problem representation is the most important stage in ill-structured problem solving process [17].

The lowest percentage of indicators for students' ill-structured problem solving skills at the problem representation stage, namely identifying relevant information (18.81\%). 47.14\% (33 students) in P1 and $44.29 \%$ (31 students) in P2 could not even identify other relevant information related to the problem. These results indicate that students have not been able to integrate their prior knowledge and experience in solving ill-structured problems. Students tend to represent problems in general, unclear, and mostly based only on the limited information provided in the problem text. Students only rewrite the information provided on the problem text given. The statements of the following students support this:

"I looked for the information needed only from the given text. I think that was enough. I could not determine what other information was needed." (Student 58)

"In problem 1, I added other information I know related to the problem. However, in problem 2, I only used the information in the text to solve the problem because I thought it was enough. I was confused about what other information I need." (Student 40)

The ill-structured problem solving process requires the implementation of a domain knowledge that is developed based on the students' prior knowledge and experiences related to the problems given [16]. Domain knowledge is a cognitive component of students, such as understanding a concept, rule, or principle [1]. Students' difficulties in identifying other relevant information related to problems were also found in [13].

\subsection{Students' Ill-Structured Problem solving Skills at the Stage of Generating and Selecting Solution}

The data in Table 1 shows that the percentage of students' ill-structured problem solving skills at the stage of generating and selecting solution $(35.71 \%)$ is the second-highest percentage after the stage of problem representation. $61.43 \%$ (43 students) in P1 and $84.29 \%$ (59 students) in P2 tend to develop solutions without an explanation of how these solutions solve the problems given. A total of $14.29 \%$ (10 students) in P1 and 7.14\% (5 students) in P2 could not even provide solutions to the problems. Most students who cannot state the solution are due to the difficulty of students in identifying the objectives of solving the problem, the factors that cause the problem, and other relevant information.

The solutions developed by students at the second stage of ill-structured problem solving are categorized into several aspects, namely based on chemical, social, economic, environmental, and health. Based on the data in Table 2, it is known that at P1, most students tended to develop solutions based on health aspect $(52.86 \%)$ rather than chemical bonding concepts $(8.57 \%)$. Some examples of solutions developed by students in P1 are described in Table 3. In P2, students tend to provide solutions based on environmental aspect $(61.43 \%)$ rather than the concepts of hydrocarbon compound and polymer $(10.00 \%)$. Some examples of solutions developed by students in $\mathrm{P} 2$ are 
described in Table 4. These results indicate that students have not been able to apply chemistry concepts to solve problems in everyday life.

Table 2. Percentage of students' solution categories

\begin{tabular}{|c|c|c|c|c|}
\hline \multirow{2}{*}{ Aspect } & \multicolumn{2}{|c|}{ Problem 1 (P1) } & \multicolumn{2}{|c|}{ Problem 2 (P2) } \\
\hline & $N^{*}$ & $\%$ & $N^{*}$ & $\%$ \\
\hline \multicolumn{5}{|l|}{ Chemistry Concept } \\
\hline a. Chemical Bonding & 6 & 8.57 & - & - \\
\hline b. Hydrocarbon and Polymer & - & & 7 & 10.00 \\
\hline Social & 11 & 15.71 & 3 & 4.28 \\
\hline Economic & 4 & 5.71 & 2 & 2.86 \\
\hline Environmental & 2 & 2.86 & 43 & 61.43 \\
\hline Health & 37 & 52.86 & 10 & 14.29 \\
\hline No Solution & 10 & 14.29 & 5 & 7.14 \\
\hline Total & 70 & 100 & 70 & 100 \\
\hline
\end{tabular}

Table 3. Examples of students' solutions and arguments to problems 1

\begin{tabular}{|l|l|}
\hline Aspect & Answers \\
\hline $\begin{array}{l}\text { Science } \\
\text { molecular polarity) }\end{array}$ & $\begin{array}{l}\text { Using any kind of soap. Because when we used any kind of soap, the hydrophobic } \\
\text { tail of any kind of soap will stick to the fat (non-polar) coat of the virus and destroy } \\
\text { the virus barrier, while the hydrophilic head of any soap will be attracted to the water } \\
\text { (polar) and dissolve the virus. (Student 4) }\end{array}$ \\
\hline Social & $\begin{array}{l}\text { Provide information to the public that antibacterial soap is no more effective than } \\
\text { ordinary soap. Because so far, people buy antibacterial soap because they do not } \\
\text { have enough socialization about the negative impact of antibacterial issues. } \\
\text { (Student 51) }\end{array}$ \\
\hline Economy & $\begin{array}{l}\text { Keep using antibacterial soap but at certain times. Because many workers depend } \\
\text { on the antibacterial soap industry in Indonesia. (Student 2) }\end{array}$ \\
\hline \multirow{5}{*}{ Environmental } & $\begin{array}{l}\text { All antibacterial soap companies should replace Triclosan and Triclocarban with } \\
\text { natural active ingredients. Because natural active ingredients are more } \\
\text { environmentally friendly. Soapy water left over from washing hands will pollute } \\
\text { water sources and soak into the ground. (Student 57) }\end{array}$ \\
\hline $\begin{array}{l}\text { Inform the public that it is better to use regular soap instead of antibacterial soap. } \\
\text { Because Triclosan and Triclocarban in anti-bacterial soap are feared to reduce the } \\
\text { body's immunity which is dangerous during the COVID-19 pandemic. (Student 26) }\end{array}$ \\
\hline
\end{tabular}

Table 4. Examples of students' solutions and arguments to problems 2

\begin{tabular}{|l|l|}
\hline Aspect & Answers \\
\hline Science & Burning single-use plastic waste must take place entirely at very high \\
(polymers and the & temperatures and sufficient oxygen conditions. Plastic waste which is wholly \\
combustion reaction of & burned will break down the plastic polymer molecules into $\mathrm{C}_{x} \mathrm{H}_{y}$ which will react \\
hydrocarbon compound) & with $\mathrm{O}_{2}$ gas to produce $\mathrm{CO}_{2}$ and $\mathrm{H}_{2} \mathrm{O}$, not dangerous $\mathrm{CO}$ gas. (Student 59) \\
\hline
\end{tabular}




\begin{tabular}{|c|c|}
\hline Aspect & Answers \\
\hline Social & $\begin{array}{l}\text { Educate the public about the impact of using single-use plastics and the } \\
\text { spread of COVID-19. Because it can increase public self-awareness regarding } \\
\text { the impact of using single-use plastic excessively for the environment. } \\
\text { Increased self-awareness can foster good habits so that people reduce their } \\
\text { use of single-use plastics. (Student 64) }\end{array}$ \\
\hline Economy & $\begin{array}{l}\text { Keep using single-use plastics but are limited, for example with paid plastic in } \\
\text { supermarkets or malls. Not economically and environmentally detrimental. The } \\
\text { turnover of single-use plastic factories has not decreased. Limiting the use of } \\
\text { plastics may reduce plastic waste a bit. (Student 8) }\end{array}$ \\
\hline Environmental & $\begin{array}{l}\text { Prohibit single-use plastics for non-medical use and replace them with cloth } \\
\text { bags, for example when shopping. Because plastic waste is tough to } \\
\text { decompose. If the use of plastic were still permitted, then the method of } \\
\text { processing plastic in Indonesia by burning it would still pollute the environment } \\
\text { because it produced } \mathrm{CO}_{2} \text { gas. } \\
\text { (Student } 46 \text { ) }\end{array}$ \\
\hline Health & $\begin{array}{l}\text { Stick to single-use plastics, but as needed. Based on the information I read, the } \\
\text { COVID-19 virus can last for } 72 \text { hours on a plastic surface, but it will decrease } \\
\text { every hour. Even so, the risk of transmitting the virus is much less than using a } \\
\text { reusable shopping bag. (Student 14) }\end{array}$ \\
\hline
\end{tabular}

The results of a holistic assessment of the solutions developed by students stated that the quality of most of the students' solutions was in the very low category. The assessment of the solution quality is based on the suitability of the student's solution to the core of the problem, the purpose of the solution, the factors causing the problem, and other relevant information described at the stage of problem representation. Based on the analysis results, the solutions developed by 40 students $(57.14 \%)$ in P1 and 45 students $(64.29 \%)$ in P2 were in the very low category. The reason is that students were unable to provide a detailed explanation of how the solution can be applied so that the problem factors can be reduced, and the problem solving objectives formulated can be achieved.

\subsection{Students' Ill-Structured Problem solving Skills at the Stage of Making Justifications}

The data in Table 1 shows that the percentage of students' ill-structured problem solving skills at the stage of making justification $(24.40 \%)$ is the lowest percentage than the other three stages. These results indicate that students are still unable to state relevant arguments (29.29\%) and provide strong evidence (19.51\%) to support their solutions. Based on the analysis results, students tend to construct irrelevant arguments and weak evidence to support the solutions developed for P1 and P2. These results also indicate that students' argumentation skills tend to be low. Most students tend to have difficulty in constructing arguments based on chemistry concepts. The students' difficulty is supported by one of the students' statements during the following interview process:

"I am confused with giving the reason for the concept of chemical bonding, but I have studied polar and non-polar molecules. So, the reasons and evidence that I use to support the solution come from the reading text. In problem 1, my solution is that the company must replace Triclosan and Triclocarban with a more natural substance, the reason being that provisional research results show it is dangerous and has been proven by the possible FDA ban. The evidence is already in the text." (Student 15)

Students' argumentation skills are needed and affect the success of the ill-structured problem solving process [16]. The reason is that ill-structured problems allow it to be solved from various points of view, so students must be able to provide reasons and relevant evidence in determining the best solution to solve these problems [1]. 


\subsection{Students' Ill-Structured Problem solving Skills at the Stage of Monitoring and Evaluating Solutions}

The data in Table 1 shows that the highest percentage of indicators for students' ill-structured problem solving skills at the monitoring and evaluations solutions stage is evaluating solutions (38.57\%). The analysis results stated that 38.57\% (27 students) in P1 and $44.29 \%$ (31 students) in P2 only stated the advantages of the solution without being fully explained and did not state the weaknesses of the solution if it was applied to solve the problem. Some other students tended to only mention the strengths and weaknesses of the solution without an explanation.

At this fourth stage, students also tend to have difficulty in formulating alternative solutions (21.07\%) that can be applied to problems. Based on the analysis results, students tend to state alternative solutions without the reasons, strengths, and weaknesses of these solutions when compared with the main solutions that have been developed. 58.57\% (41 students) in P1 and $60.00 \%$ (42 students) in P2 could not even state alternative solutions to the problems given. Students tend to solve ill-structured problem solving, such as solving well-structured problems where there is only one correct solution for each problem. Based on the results of the interviews, most students also stated that they had never worked on illstructured problem-based questions, especially in chemistry learning, so they had difficulty in formulating alternative solutions to solve problems.

"In my opinion, the solution I gave for question number 5 is the best. So, there is no other solution. That is the solution." (Student 1)

"I do not know the alternative solution. I have not found the right solution for that problem. There seems to be only one solution." (Student 10)

Some other students who can formulate alternative solutions generally only state solutions without an evaluation of the strengths and weaknesses of the alternative solution compared to the main solution. This condition is supported by the statement of one of the following students:

"So, I have several solutions for every problem. After I analysed the most suitable solution, I chose one more solution from the several options as an alternative. I think both the alternative and the main solution must be adequate to solve the problem. I have not found the weakness of the alternative solution." (Student 15)
At the stage of monitoring and evaluating solutions, metacognitive skills are needed [1]. The difficulty of students in evaluating the strengths and weaknesses of the main solutions and formulating alternative solutions can be caused by the students' poor metacognitive skills [9].

\section{CONCLUSION}

In the process of solving chemistry problems related to COVID-19 issues, the highest percentage of students' ill-structured problem solving skills occurred at the stage of problem representation, while the lowest average percentage occurred at the stage of making justifications. Students tend to have difficulty identifying other relevant information related to the problem at the stage of problem representation, including identifying chemistry concepts that can be applied to solve the problem. These conditions affect the solutions developed by students. Students tend to develop solutions to given problems based on environmental, health, social, and economic aspects rather than based on chemistry concepts. Only about $10 \%$ of students in this study were able to develop solutions based on the concepts of chemical bonding, hydrocarbons, and polymers. These results indicate that students have not been able to apply chemistry concepts to solve problems in everyday life. Students also have difficulty in stating relevant arguments and providing strong evidence to support the solution. The results of this study indicate that teachers need to apply more ill-structured problem solving related to chemistry concepts in chemistry learning process.

\section{ACKNOWLEDGMENTS}

The authors sincerely thank to LPDP (Lembaga Pengelolaan Dana Pendidikan), Ministry of Finance, Republic of Indonesia for research funding support through Education Scholarship Program.

\section{REFERENCES}

[1] D. Jonassen, Instructional Design Models for Well-Structured and Ill-Structured ProblemSolving Learning Outcomes, Educational Technology Research and Development 45(1) (1997) 65-94. DOI: https://doi.org/10.1007/bf02299613

[2] OECD, The PISA 2003 Assessment Framework Mathematics, Reading, Science and Problem Solving Knowledge and Skills, OECD Publishing, 2003. 
[3] OECD, PISA 2018 Results Combined Executive Summaries Volume I, II \& III, OECD Publishing, 2019.

[4] D. Jonassen, Using Cognitive Tools to Represent Problems, Journal of Research on Technology in Education 35(3) (2003) 362-381. DOI: https://doi.org/10.1080/15391523.2003.1078239 $\underline{1}$

[5] D. Johanssen, Toward A Design Theory of Problem Solving, Educational Technology Research and Development 48(4) (2000) 63-85. DOI: https://doi.org/10.1007/BF02300500

[6] K. Broman, S. Bernholt, I. Parchmann, Using Model-Based Scaffolds to Support Students Solving Context-Based Chemistry Problems, International Journal of Science Education 40(10) (2018) 1176-1197. DOI: https://doi.org/10.1080/09500693.2018.1470350

[7] D. Jonassen, Assessing Problem Solving, in: J.M. Spector, M. Merrill, J. Ellen, M. Bishop (Eds.), Handbook of Research on Educational Communication and Technology, Springer, 2014. DOI: https://doi.org/10.1007/978-1-46143185-5_22

[8] I. Choi, K. Lee, Designing and Implementing A Case-Based Learning Environment for Enhancing Ill-Structured Problem Solving: Classroom Management Problems for Prospective Teachers, Educational Technology Research and Development 57(1) (2009) 99-129. DOI: https://doi.org/10.1007/s11423-008-9089$\underline{2}$

[9] X. Ge, S.M. Land, A Conceptual Framework for Scaffolding III-Structured Problem-Solving Processes Using Question Prompts and Peer Interactions, Educational Technology Research and Development 52(2) (2004) 5-22. DOI: https://doi.org/10.1007/BF02504836

[10] G. Shilo, N. Ragonis, A New Approach to HighOrder Cognitive Skills in Linguistics: ProblemSolving Inference in Similarity to Computer Science, Journal of Further and Higher Education 43(3) (2017) 1-14. DOI: https://doi.org/10.1080/0309877X.2017.136151 $\underline{5}$

[11] H. Byun, J. Lee, F.A. Cerreto, Relative Effects of Three Questioning Strategies in Ill-Structured, Small Group Problem Solving, Instructional
Science 42(2) (2014) 229-250. DOI: https://doi.org/10.1007/s11251-013-9278-1

[12] D. Eseryel, D. Ifenthaler, X. Ge, Validation Study of A Method for Assessing Complex IllStructured Problem Solving by Using Causal Representations, Educational Technology Research and Development 61(3) (2013) 443463. DOI: https://doi.org/10.1007/s11423-0139297-2

[13] K. Laxman, A Conceptual Framework Mapping the Application of Information Search Strategies to Well and Ill-Structured Problem Solving, Computers \& Education 55(2) (2010) 513-526. DOI:

https://doi.org/10.1016/j.compedu.2010.02.014

[14] E. Yuriev, S. Naidu, L.S. Schembri, J.L. Short, Scaffolding The Development of ProblemSolving Skills in Chemistry: Guiding Novice Students Out of Dead Ends and False Starts, Chemistry Education Research and Practice 18(3) (2017) 486-504. DOI: https://doi.org/10.1039/C7RP00009J

[15] R.H. Collins, J. Sibthorp, J. Gookin, Developing III-Structured Problem-Solving Skills through Wilderness Education, Journal of Experiential Education 39(2) (2016) 179-195. DOI: https://doi.org/10.1177\%2F1053825916639611

[16] N. Shin, D. Jonassen, S. Mcgee, Predictors of Well-Structured and Ill-Structured Problem Solving in an Astronomy Simulation, Journal of Research in Science Teaching 40(1) (2003) 6-33. DOI: https://doi.org/10.1002/tea.10058

[17] X. Ge, S.M. Land, Scaffolding Students' Problem-Solving Processes in an Ill-Structured Task Using Question Prompts and Peer Interactions, Educational Technology Research and Development 51(1) (2003) 21-38. DOI: https://doi.org/10.1007/BF02504515

[18] S. Rahayu, Socio-scientific issues (SSI) in chemistry education: Enhancing both students' chemical literacy \& transferable skills, in: Journal of Physics: Conference Series, vol. 1227, IOP Publishing, Bristol, 2019, pp. 1-8. DOI: https://doi.org/10.1088/1742$\underline{6596 / 1227 / 1 / 012008}$

[19] P.E. Childs, S.M. Hayes, A.O. Dwyer, Chemistry and everyday life: Relating secondary school chemistry to the current and future lives of students, in: I. Eilks, A. Hofstein (Eds.), 
Relevant Chemistry Education - From Theory to Practice, Sense Publishers, Rotterdam, 2015, pp. 978-994. DOI: https://doi.org/10.1007/97894-6300-175-5 3

[20] T.D. Sadler, W.L. Romine, M.S. Topçu, Learning Science Content through SocioScientific Issues-Based Instruction: A MultiLevel Assessment Study, International Journal of Science Education 38(10) (2016) 1622-1635. DOI:

https://doi.org/10.1080/09500693.2016.1204481

[21] D.L. Zeidler, S. Kahn, Dana L. Zeidler, It's Debatable! Using Socio-scientific Issues to Develop Scientific Literacy, K-12, NSTA Press, 2014.

[22] Zamakhsyari, S. Rahayu, Fostering Ill-structured problem-solving skills of chemistry students using socioscientific issues as learning contexts, in: AIP Conference Proceeding, vol. 2215, AIP Publishing, College Park, Maryland, 2020, pp.16. DOI: https://doi.org/10.1063/5.0000533

[23] E. Capkinoglu, S. Yilmaz, G. Leblebicioglu, Quality of Argument by Seventh-Graders in Local Socioscientific Issues, Journal of Research in Science Teaching 57(6) (2019) 827-855. DOI: https://doi.org/10.1002/tea.21609

[24] T.L. Overton, N.M. Potter, Investigating Students' Success in Solving and Attitudes towards Context-Rich Open-Ended Problems in Chemistry, Chemistry Education Research and Practice 12(3) (2011) 294-302. DOI: https://doi.org/10.1039/C1RP90036F
[25] T.D. Sadler, P. Friedrichsen, L. Zangori, L.I. Ke, Technology Supported Professional Development for Collaborative Design of COVID-19 Instructional Materials, Journal of Technology and Teacher Education 28(2) (2020) 171-177.

[26] J. Milbourne, E. Wiebe, The Role of Content Knowledge in Ill-Structured Problem Solving for High School Physics Students, Research in Science Education 48(1) (2018) 165-179. DOI: https://doi.org/10.1007/s11165-016-9564-4

[27] D. Eseryel, X. Ge, D. Ifenthaler, V. Law, Dynamic Modeling as a Cognitive Regulation Scaffold for Developing Complex ProblemSolving Skills in an Educational Massively Multiplayer Online Game Environment, Journal of Educational Computing Research 45(3) (2011) 265-286.

DOI: https://doi.org/10.2190\%2FEC.45.3.a

[28] T. Overton, D.J. McGarvey, Development of Key Skills and Attributes in Chemistry, Chemistry Education Research and Practice 18(3) (2017) 401-402.

DOI: https://doi.org/10.1039/C7RP90006F

[29] J.W. Creswell, Educational Research: Planning, Conducting, and Evaluating Quantitative and Qualitative Research, Pearson Education, 2012.

[30] J.R. Fraenkel, N.E. Wallen, How to Design and Evaluate Research in Education, The McGrawHill Companies, 2009. 